\title{
Hupa Language
}

National Cancer Institute

\section{Source}

National Cancer Institute. Hupa Language. NCI Thesaurus. Code C153952.

An Athabaskan language spoken along the lower course of the Trinity River in Northwestern California by the Hupa people. 